\title{
Improving Effectiveness of Interdisciplinary Design Project: Lessons Learnt
}

\section{Dr. Priya A. Manohar, Robert Morris University}

Dr. Priyadarshan Manohar is an Associate Professor of Engineering at Robert Morris University, Pittsburgh, Pa. He has a Ph.D. in Materials Engineering (1998) and master's degree in Computer Science (1999) from University of Wollongong, Australia and holds a bachelor of Engineering (Metallurgical Engineering) degree from College of Engineering, Pune India (1985). He has worked as a post-doctoral fellow at Carnegie Mellon University, Pittsburgh $(2001$ - 2003) and BHP Institute for Steel Processing and Products, Australia (1998 - 2001). Dr. Manohar held the position of Chief Materials Scientist at Modern Industries, Pittsburgh (2003 - 2004) and Assistant Manager (Metallurgy Group), Engineering Research Center, Telco, India (1985 - 1993). He has published over 50 papers in peer-reviewed journals and conferences including a 2007 Best Paper Award by the Manufacturing Division of American Society for Engineering Education (ASEE), three review papers and three book chapters. He has participated in numerous national and international conferences. He is a member of ASM International, TMS, ACerS, AIST, ASEE, IMEA, and a registered Chartered Professional Engineer. Dr. Manohar's research interests include mathematical and computer modeling of materials behavior, thermomechanical processing of steels and other metallic materials, microstructural characterization, advanced manufacturing and structure - property relationships. He has conducted a number of technical failure investigations, consulted on various materials-related problems, and acted as an expert witness in the Court of Law.

\section{Dr. Cathleen Jones, Robert Morris University}

Associate Professor of Marketing Dr. Cathleen Jones's areas of specialization include Marketing Research, Social Media for Marketing, and International Marketing. Dr. Jones holds a Doctor of Science in Information Systems and Communication. Her field project is titled "Exploring the Factors Affecting Food Choice at Restaurants with Special Emphasis on the Roles Played by Menus, Health Information, and Health Icons.” 


\section{Improving Effectiveness of Interdisciplinary Design Project: Lessons Learnt}

\section{Background}

It has been long recognized that one of the most important aspect of delivering high quality engineering education is to provide the students with as much hands-on, real world experience as possible. The knowledge level of graduates is often not to a level of expectation by the employers because there is a gap between what students learn at school and what they are required to do in practice after graduation. In this regards, Society for Manufacturing Engineers (SME) survey ${ }^{1,2)}$ has also identified several knowledge gaps including the following:

- Product and Process Design

- Project Management

- Team Work

- Communication

- Problem Solving and others

In particular, product design has been identified as a complex, integrated problem ${ }^{3)}$ that covers a wide range of knowledge including engineering (technology, techniques, material and processing, reliability, robust design), ergonomics (operation, safety, usability), business (marketing, management, planning, corporate identity), aesthetics (form, visualization, style), and social, environmental, and cultural issues. Therefore it is most important that product design incorporates interdisciplinary approach as much as possible.

Engineering educators have been addressing these issues by creating curricula that involve interdisciplinary team work over a long period of time. For example it is reported that ${ }^{4)}$ students in a Manufacturing Processes class benefited by working together with a medical doctor and a practicing surgeon to design and subsequently manufacture prototype of a new medical device to improve a minimally-invasive surgical procedure. Product design in the emerging field of mechatronics has been taught effectively at NY City College of Technology ${ }^{5)}$ by developing multi-disciplinary design teams and creating joint teaching sessions where students gained significant experience in team work, time management, and collaboration and cooperation between mechanical, electrical and electronics engineering, along with industrial design, computer control systems, embedded systems and intelligent software systems. At graduate level, engineering education has also been focused on encouraging product innovation and creativity training ${ }^{6,7)}$. Another approach used to incorporate broad education necessary in engineering design is by applying the concept of Product Archeology as a way of reverse engineering to understand how products are designed and created. The incorporation of broader array of measures allows the study of sustainability ${ }^{8,9)}$, societal, environmental, ethical and global issues in product design ${ }^{10,11,12)}$. There are also examples of broadening design methodologies by creating products that may used by people with the widest range of abilities (e.g. people with disabilities) and operating within widest possible operating conditions ${ }^{13)}$. 
In the spring of 2006, a junior year level Product and Tool Design course was delivered concurrently with appropriate complementing courses from Manufacturing Engineering, and Marketing departments. This initial effort of developing and delivering interdisciplinary course has been quite successful. The details of this work were reported in ASEE conference ${ }^{14}$. To summarize the work done so far, the Interdisciplinary Design Studies (IDS) project was a unique curricular experiment by virtue of two features: Firstly, because the course was offered for mainly junior (along with some sophomore) students and not for senior or graduate students as is usually the case. It was felt that the engineering students in their junior year were well-prepared to undertake the product design and development challenge because by that time they have gained an understanding of the properties of engineering materials, been exposed to the basics of mechanical design and obtained hands-on experience with manufacturing processes. These prerequisite building blocks are courses related to the topics of Engineering Materials, Statics and Strength of Materials, Engineering Graphics, and Production Engineering. The marketing students are also ready to take on the challenge of Marketing Research in their junior year. The IDS course also prepares the engineering students to take on the Capstone Design course in their senior year. The second novel feature of IDS project is that it involved concurrent delivery of two junior level courses where the course content of the courses was synchronized. The courses involved in this project were ENGR 3650: Product and Tool Design (Engineering Department), and MARK 3700: Marketing Research (Marketing Department). Both the classes have the same number of credits (3) available to the students. Engineers take ENGR 3650 while marketing students take MARK 3700. Both classes are required core classes for their respective majors. The course contents of both the courses were modified as appropriate and the order of delivery of the topics was altered so that the students obtained a complimentary set of skills to work on their product development project as a team. The student teams containing one or more representatives from engineering and marketing disciplines developed a product concept for consumer market based on some specified design guidelines, criteria and constraints. The competing concepts were tested by the marketing students in the field and gave feedback to the team. The engineering students then manufactured a prototype for the selected concept. The teams wrote a detailed project report and made oral presentation as a part of their project deliverables.

The course has been offered continuously since then for the past seven years with a record number of students enrolled in this course in the Spring 2012 term. The success of the course is largely attributed to the continuous improvement efforts undertaken by the faculty involved based on the lessons learnt and an analysis of student feedback surveys. This paper outlines the hurdles, bottlenecks encountered in the initial phases of course development and the solutions found and implemented later on to address the issues that cropped up.

\section{Assessment of the Effectiveness of Interdisciplinary Course Delivery}

The interdisciplinary course delivery was delivered for the first time in the Spring of 2006 and thus it was important to know how effective it was in terms of student learning, student satisfaction, student performance and ABET outcomes assessment. The student satisfaction survey was developed and was approved by the university's Institutional Review Board (IRB). The IRB approval was renewed in year 2010 for subsequent use of the survey tool. The results of course effectiveness assessment are presented in the following sections 


\title{
2.1 Pre- and Post- Course Student Survey
}

Students in the Marketing and Engineering classes were asked to take the surveys in their first class before they are introduced to the course curriculum to establish a "before" baseline for their understanding of the product design and development process. The survey was later given to assess their responses to the survey questions. Some of the questions included in the survey are:

1. Describe the role of the designer in new product development.

2. Describe the role of the engineer in new product development.

3. Describe the role of the market researcher in new product development.

4. How is qualitative research different from quantitative research? Briefly explain.

5. What is the difference between a prototype and a model?

6. How do aesthetics affect the success of a product?

7. Why is the relationship between the user, the object and the environment in which it is used important?

8. What are the major benefits achieved through the collaboration of the designer, engineer, and market researcher throughout the product development? Please be specific and list as many as you can think of.

9. What difficulties arise when designers, engineers, and market researchers try to collaborate? Please be specific and list as many as you can think of.

Some of the pre- and post-responses of the students to the above questions are:

About aesthetics:

Pre-response:

Post-response: "it is the bait - aesthetics help draw potential customers in"

"good aesthetics caught the "wow factor 'for most people!"

About role of engineer:

Pre-response: "engineer takes a design and makes it possible and cost effective"

Post-response: "makes a product that meets customer needs!"

\begin{abstract}
About role of market researcher:
Pre-response: "market researcher identifies a need and a target market that the product will be developed for"

Post-response: "determines market size, identifies customer needs, assesses potential for entering a market!"
\end{abstract}

From these samples it is clear that interdisciplinary project has deepened engineers' understanding of the role of marketing research professionals in the product design process, learnt what they do and developed a level of maturity in their responses. 


\subsection{Student Satisfaction Survey}

The IRB-approved student satisfaction survey was given at the end of the term (during the last class for the term) to assess their responses to the survey questions. Some of the questions included in the student satisfaction survey are:

1. How would you rate the interaction between the three classes during the in-class meetings? (Circle one)

$\begin{array}{cccccc}\text { Excellent } & \text { Very Good } & \text { Good } & \text { Fair } & \text { Poor } & \text { Extremely Poor } \\ 1 & 2 & 3 & 4 & 5 & 6\end{array}$

Please explain your rating:

2. How valuable were the Marketing Research presentations to your work in the course? (Circle one)

Check here if you did not attend the presentation event

$\begin{array}{ccccc}\text { Extremely } & \text { Very } & \text { Moderately } & & \text { Not at all } \\ \text { Valuable } & \text { Valuable } & \text { Valuable } & \text { Valuable } & \text { Valuable } \\ 1 & 2 & 3 & 4 & 5\end{array}$

Please explain your rating:

3. How would you rate the Engineering presentation event overall? (Circle one) Check here if you did not attend the presentation event

$\begin{array}{cccccc}\text { Excellent } & \text { Very Good } & \text { Good } & \text { Fair } & \text { Poor } & \text { Extremely Poor } \\ 1 & 2 & 3 & 4 & 5 & 6\end{array}$

Please explain your rating:

4. This experience helped me to better understand 3-D Computer Modeling (Circle one)

$\begin{array}{ccccc}\text { Strongly } & & \text { Neither Agree } & & \text { Strongly } \\ \text { Agree } & \text { Agree } & \text { Nor Disagree } & \text { Disagree } & \text { Disagree } \\ 1 & 2 & 3 & 4 & 5\end{array}$

5. This experience helped me to better understand Engineering Product Design. (Circle one)

$\begin{array}{ccccc}\text { Strongly } & & \text { Neither Agree } & & \text { Strongly } \\ \text { Agree } & \text { Agree } & \text { Nor Disagree } & \text { Disagree } & \text { Disagree } \\ 1 & 2 & 3 & 4 & 5\end{array}$

6. This experience helped me to better understand Marketing Research. (Circle one)

$\begin{array}{ccccc}\text { Strongly } & & \text { Neither Agree } & & \text { Strongly } \\ \text { Agree } & \text { Agree } & \text { Nor Disagree } & \text { Disagree } & \text { Disagree } \\ 1 & 2 & 3 & 4 & 5\end{array}$

The statistical analysis of these data sets is currently underway. However, it appears that students were moderately happy with marketing presentations and surveys while the students were not very happy about the communication and the effectiveness of the interaction. Engineers also felt that marketing folks came up with product ideas that were not realistic - such as developing machine washable "ipod" kind of device or a flexible and bouncy (rubbery) electronics display! The lessons learnt from this analysis are given in more detail later on in Section 5 in this paper. 


\subsection{ABET Course Outcomes Assessment}

The applicable ABET criteria for this course and their corresponding evaluations based on student assessment tasks taken from Manohar et al. ${ }^{14)}$ are presented in Table 1 shown below.

Table 1: Examples of student evaluation tasks in the context of applicable ABET criteria.

\begin{tabular}{|c|c|}
\hline Applicable ABET Criterion & Assessment Task \\
\hline $\begin{array}{l}\text { \#1 an ability to apply } \\
\text { knowledge of mathematics, } \\
\text { science and engineering }\end{array}$ & $\begin{array}{l}\text { Estimate the production cost (manufacturing + overhead) for a simple } \\
\text { product such as a floppy disk, ball-point pen, jackknife, or a baby's } \\
\text { toy. The product will typically have less than } 10 \text { components. } \\
\text { Remember that the upper bound for your estimate is } 50-70 \% \text { of the } \\
\text { retail price. }\end{array}$ \\
\hline $\begin{array}{l}\# 2 \text { : an ability to design and } \\
\text { conduct experiments, as well } \\
\text { as to analyze and interpret } \\
\text { data }\end{array}$ & $\begin{array}{l}\text { Plan for Subtract and Operate (SOP) procedure and teardown analysis } \\
\text { Which features / properties will be tested? Methods of testing? Tools } \\
\text { needed? How much accuracy / precision is required? }\end{array}$ \\
\hline $\begin{array}{l}\text { \#3: an ability to design a } \\
\text { system, component or process } \\
\text { to meet desired needs }\end{array}$ & $\begin{array}{l}\text { Identify customer needs for the product you have chosen to redesign. } \\
\text { Employ interview template provided in lecture notes. Determine } \\
\text { importance rating for each need. }\end{array}$ \\
\hline $\begin{array}{l}\text { \#4: an ability to function on } \\
\text { multidisciplinary teams }\end{array}$ & $\begin{array}{l}\text { Multidisciplinary term project - details are provided in section in this } \\
\text { paper }\end{array}$ \\
\hline $\begin{array}{l}\# 5: \text { an ability to identify, } \\
\text { formulate, and solve } \\
\text { engineering problems }\end{array}$ & $\begin{array}{l}\text { A manufacturing company plans to enter the market for school bags. } \\
\text { Assume that the school bags are currently sold in the market at a rate } \\
\text { of } 1,000,000 / \text { year. Assume that the manufacturing company has hired } \\
\text { a single distributor who would account for } 30 \% \text { of the total sales of } \\
\text { the school bags. The company would like to estimate the quantity to } \\
\text { manufacture }(Q) \text { per year given that their customer survey has } \\
\text { resulted in the following data: } \mathrm{C}_{\text {definitely }}=0.4, \mathrm{C}_{\text {probably }}=0.2, \mathrm{~F}_{\text {definitely }}= \\
0.4, \mathrm{~F}_{\text {probably }}=0.3\end{array}$ \\
\hline $\begin{array}{l}\text { \#6: An understanding of } \\
\text { professional and ethical } \\
\text { responsibilities }\end{array}$ & $\begin{array}{l}\text { Conduct information search for the manufacturer who makes the } \\
\text { product you selected for benchmarking. Find out as much information } \\
\text { as you can about the manufacturer regarding: company mission and } \\
\text { vision, history, information about product, features, materials, } \\
\text { company, manufacturing locations, problems, customers, market } \\
\text { share, vendors; statistics on employment, payroll, inventories, capital } \\
\text { expenditures, manufacturing costs, financial status, other products } \\
\text { made by this company. Information search must be conducted by } \\
\text { employing only the ethical means as discussed in the class. } \\
\text { Summarize the information and include it in the assignment solution. }\end{array}$ \\
\hline
\end{tabular}


Table 1 (contd.): Examples of student evaluation tasks in the context of applicable ABET criteria.

\begin{tabular}{|l|l|}
\hline Applicable ABET Criterion & \multicolumn{1}{c|}{ Assessment Task } \\
\hline $\begin{array}{l}\text { \#7: an ability to communicate } \\
\text { effectively }\end{array}$ & Progress report and presentation, final report and presentation \\
\hline $\begin{array}{l}\text { \#10: A knowledge of } \\
\text { contemporary issues }\end{array}$ & $\begin{array}{l}\text { What are the main differences between benchmarking based on } \\
\text { product metrics and benchmarking based on perceived customer } \\
\text { satisfaction? }\end{array}$ \\
\hline $\begin{array}{l}\text { 11: an ability to use the } \\
\text { techniques, skills, and } \\
\text { modern engineering tools } \\
\text { necessary for engineering } \\
\text { practice }\end{array}$ & $\begin{array}{l}\text { Use of CNC machines, rapid prototyping, hot Isostatic press, machine } \\
\text { shop, AutoCAD, SolidWorks etc. to design and manufacture their } \\
\text { prototype. }\end{array}$ \\
\hline
\end{tabular}

The student performance for the Spring ' 12 terms in terms of ABET outcomes assessment is shown in Figure 1.

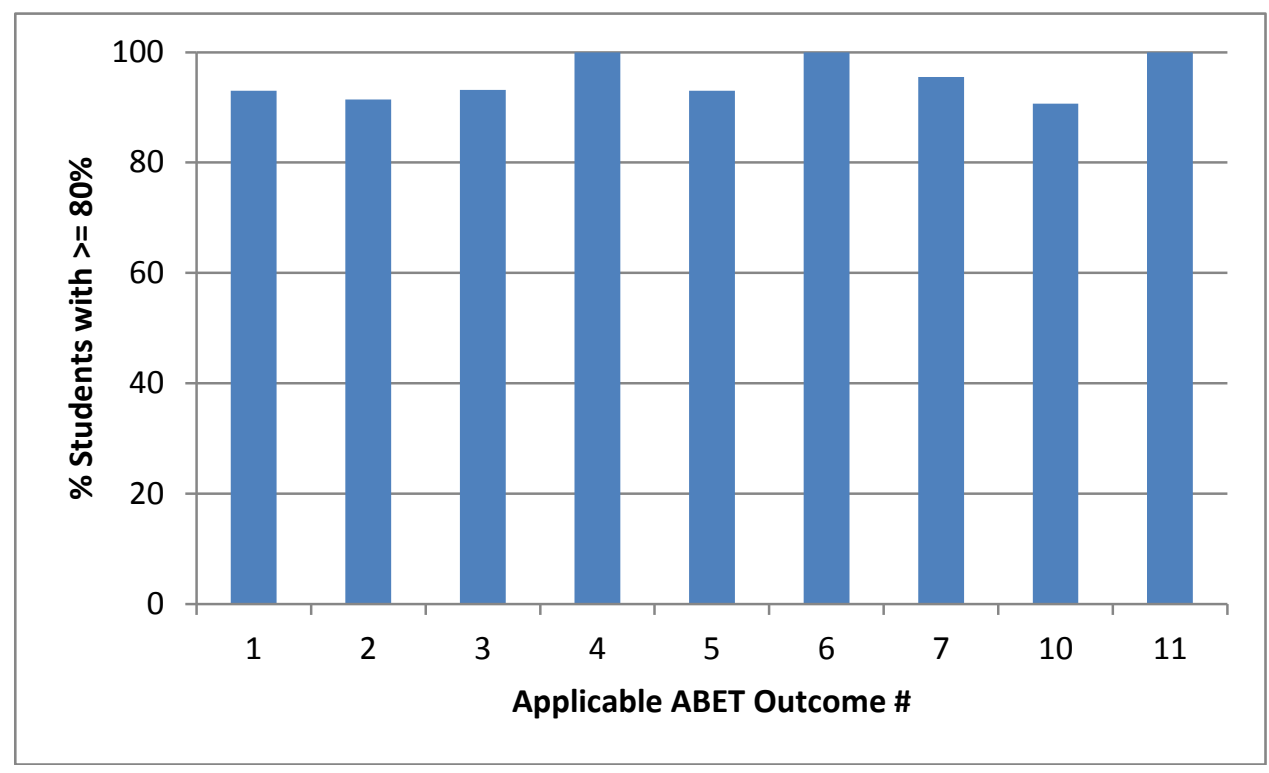

Figure 1: Class performance with respect to ABET outcomes. (The current university-designated benchmark for class performance is: $80 \%$ of the class scores $>=80 \%$ in the outcomes assessment for each of the applicable ABET criteria).

It can be seen from Figure 1 that the class performance in this course exceeds the universitydesignated benchmark (at least $80 \%$ students in the class score at least $80 \%$ marks) in all of the applicable ABET outcome assessment tasks. Student grading is based on both individual tasks in the form of assignments and exams (weight - 70\% towards the final grade) and also the interdisciplinary team work (weight - 30\% towards final course grade). The assignments are so designed that they help students create pieces that they can put together later on towards their final project report. 


\subsection{ABET Track-Specific Outcomes Assessment}

According to the existing course description, the following ABET track-specific outcomes are applicable for this course:

- Outcome M1: Proficiency in materials and manufacturing processes, understand the influence of manufacturing processes on the behavior and properties of materials

- Outcome M2: Proficiency in process, assembly, and product engineering and understand the design of products and the equipment, tooling, and environment necessary for their manufacture

- Outcome M3: Appreciate the necessity for manufacturing competitiveness and understand how to create competitive advantage through manufacturing planning, strategy, and control

The student performance for the Spring ' 12 term in terms of ABET Track-Specific outcomes assessment is shown in Figure 2.

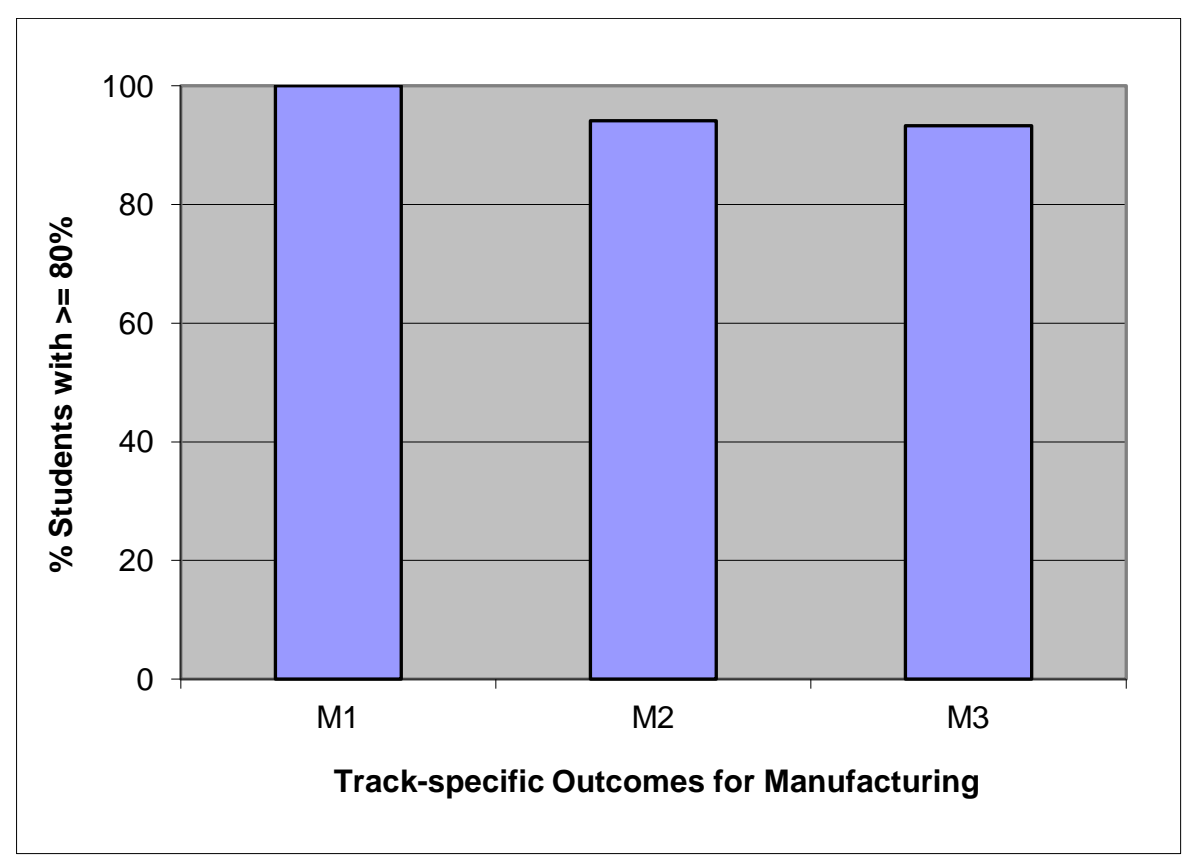

Figure 2: Class performance with respect to track-specific outcomes. (The current universitydesignated benchmark for class performance is $80 \%$ ).

The data shown in Figure 2 demonstrate that the class performance in this course exceeds the university-designated benchmark (at least $80 \%$ of the students achieve $80 \%$ points in the assessment tasks) for all of the applicable track-specific outcomes. 


\subsection{Student Instructional Report Results}

Finally, the end-of-term student satisfaction survey was conducted using Student Instructional Report II (SIR II). In the present case, the number of students that participated in the survey was between seven and fourteen. The survey is analyzed and a third party issues reports based on the survey data. These data given in Table 2 clearly shows that the students felt that they learned more and their interest level and knowledge increased significantly after undertaking the interdisciplinary class..

Table 2: Selected survey items from SIR II reports for Spring '10, '11, and '12 terms.

\begin{tabular}{|c|c|}
\hline Item & Mean $\pm \mathbf{0 . 3}$ \\
\hline Course Organization and Planning & 4.42 \\
\hline Faculty / Student Interaction & 4.18 \\
\hline Effectiveness of Student Assessment Tasks & 4.38 \\
\hline Course Outcomes (interest, learning, knowledge) & 3.74 \\
\hline Use of Supplementary Teaching Tools & Very Effective \\
\hline Overall Evaluation & 4.10 \\
\hline
\end{tabular}

\section{Interdisciplinary Term Project Specifications}

The details of the interdisciplinary term project specifications are given below.

Purpose: The purpose of this project is to give students a hands-on opportunity to implement the ideas and techniques you learn in the class to design and develop a consumer product. The project is the major lab component of the course and is worth $30 \%$ of the final grade.

Objectives: The objectives are to design a functional tool or a consumer product and subsequently manufacture a functional prototype of it. Keep a systematic record or log book of all your activities. A tool can be a kitchen, gardening, wood or metal working tool. A consumer product may be a table lamp, broom, trashcan, a musical instrument, a toy etc. Write a detailed project report and make a presentation based on the project work at the end of the term.

Background: A typical group is anticipated to consist of 2- 3 engineering students and $4-6$ marketing students. Each group is responsible for developing appropriate channels for communication, both on and off campus, with their team members e.g. e-mail, cell / home / work phones, organizes meetings and so on.

Design Guidelines: The guidelines for designing a product or a tool are as follows:

- Must perform a useful task or a function

- Contain at least five (5) distinct parts and requires five (5) different manufacturing + assembly operations to build

- Retail under $\$ 20$, prototype manufacturing cost less than $\$ 100$ 
- Be benchmarkable, which means that there are similar commercially-made products available for comparison

- Be ergonomically sound and safe to use

- Choose appropriate materials and processes with a view to maximize energy conservation, minimize environmental impact and facilitate sustainable development via recycling / reuse.

- Be something that you can realistically prototype without costing a fortune. Prototype must look and feel as much like the final design as possible

- Have some special characteristic(s) that will make it marketable e.g. added functionality, pleasing appearance, lightweight etc.

- Try to come up with a concept for a tool or product that you would like to own and that you want to work on.

\section{Course Implementation}

\subsection{IDS Course Delivery Tasks and Timeline}

Engineering and marketing students work together to develop ideas for new product(s). Marketing students test these ideas to find out if the products have the potential to be successful in a market place. The first four weeks of the term are devoted to generating concepts and selecting $2-3$ ideas for marketing students to work with. Marketing students will subsequently continue their work on the selected ideas in Weeks \#4-8, and make final presentations based on their work in Week \#9. While marketing students are conducting their field testing, engineering students work on other product development aspects such as benchmarking, subtract and operate procedure, plan for manufacturing, and development of bill of materials. Engineering students will assist in developing the marketing presentation (if needed) and attend the final presentation by their marketing team members. The presentations made by the marketing students will be assessed by a panel of marketing professionals who will deliberate and select one idea per group that has the most potential of being successful in the market place. For the students, it represents an opportunity for all students to learn about the marketability of their proposed designs. Engineering students are expected to attend team meetings listed in weeks \#2, \#4, and \#8. Engineering students will subsequently manufacture a prototype, preferable a comprehensive prototype in weeks \#9 - \#13 and make a presentation based on their work in Week \#14. Marketing students and faculty also attended the final presentation by engineering students.

\subsection{IDS Project Deliverables}

The interdisciplinary engineering and marketing student teams brainstorm for various product ideas and finally select two of these ideas per team for further exploration. Subsequently, each marketing team narrows down their choice to one idea that they study in detail. They conduct marketing survey and data analysis for these product ideas and present their results to the invited panel of marketing professionals and also to entire student body and faculty members. Each engineering group picks up the recommended product idea to continue with further product realization process including design for manufacturing and assembly. Finally, the engineering students manufacture a proof-of-concept, look-alike, work-alike or comprehensive prototype. Examples of student projects and prototypes that they built in this course are shown in Figure 3. 


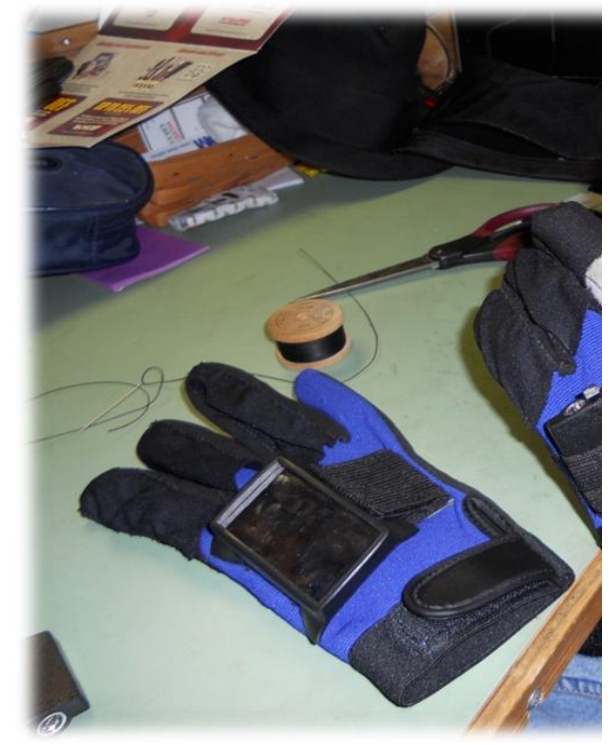

(a)

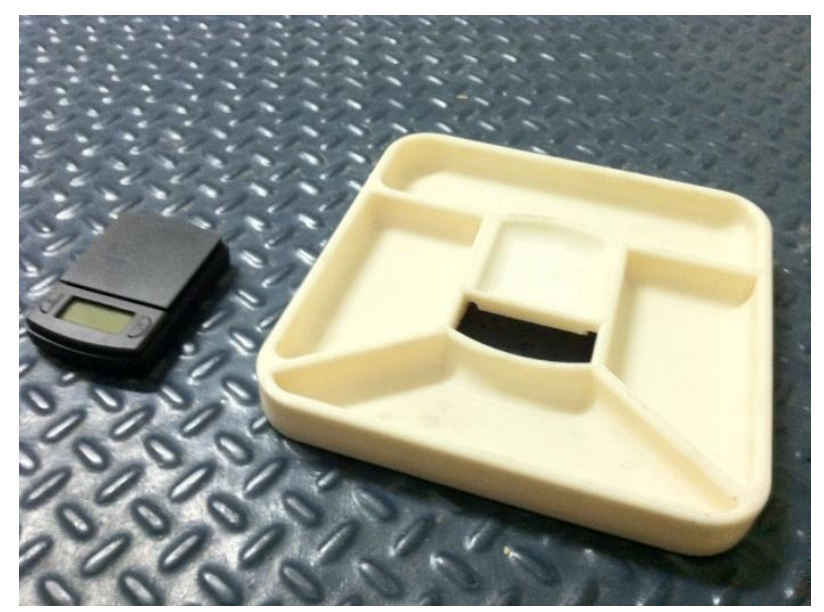

(b)

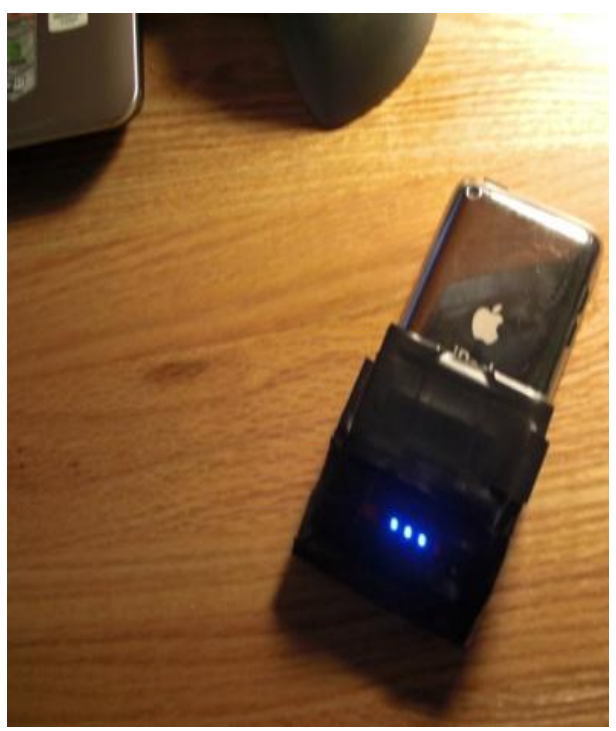

(c)

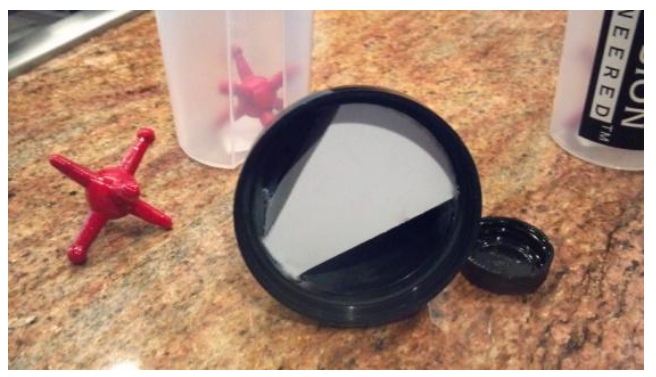

(d)

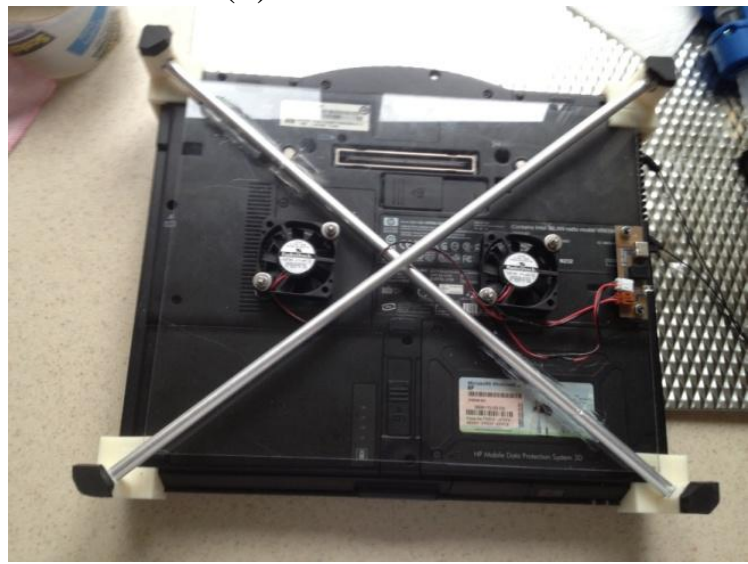

(e)

Figure 3: Examples of the prototypes of the products (re)designed and manufactured by the students: (a) Heated, lighted, magnetic outdoor hand gloves, (b) Healthy meal plate, (c) iSaver cell phone charger, (d) athletic drink bottle with supplement container and stirrer, and (e) laptop cooling pad. 
The entire product development process ended for engineering students with a detailed design report and an oral presentation for the entire student body (in a show and tell session) at the end of the term. The intense work schedule kept students quite engaged with this project throughout the term and they found multidisciplinary experience to be interesting and enriching.

\section{Lessons Learnt}

As mentioned in Section 2.1 and 2.2 in this paper, the students were given pre- and post-course surveys and student satisfaction surveys. While full statistical analysis of the data is currently underway, a review of the student feedback survey tool has highlighted many important lessons to be learnt to improve the design, delivery and effectiveness of the IDS course. Some of these lessons have already been implemented as the course has evolved over the past seven years while some others will be implemented in future iteration of this course. The lessons learnt so far are summarized as follows:

- Engineering students feet rushed - a lack of time to work on product idea, and build all the 'cool' features into their prototype. They would have liked to have had more time to build their products. The course timeline was therefore adjusted so that engineering students would get at least five weeks to design and manufacture their prototype. This amount of time may not be enough but it is not possible to accelerate the idea generation phase too much. This first phase of product development is crucial and time consuming and any short cuts in this stage may significantly compromise the concept generation and concept selection phases which determine the quality and marketability of the product being designed.

- Engineering students also believed that even though the work load in the course was higher than other comparable classes, it was a 'fun' class because it was a hands-on class and they got to build a product. It is important to note here that the students are more engaged and involved in their learning process via the many hands-on activities that product building entails.

- It became clear that the engineering students were benefited by working with marketing students as they gained valuable insight into several important aspects of product design: (a) who are the potential customers for the product? (b) how much are they willing to pay for the product? and (c) what are the features of the product that the customers like or which product features they would like to have. The students also obtained additional information based on the feedback received by the marketing students on several other aspects of the product design such as material used, texture, color, weight, accessories, options for product architecture, style and aesthetics.

- The course contents of engineering and marketing courses were needed to be substantially synchronized so that the students acquired complementing skills to work on their interdisciplinary design project.

- The course teaching time schedules were adjusted to make sure students were able to hold face-to-face joint meetings to work together on their projects. A lot of students commented that "communication" outside of the classroom time was difficult and that is an area that they would like to improve upon! In the current world that is full of any number of communication channels (texting, twitter, ubiquitous cell phones, IM chat, 
Facebook, e-mail and so on), communication gap is still a major issue! In our opinion, learning to be effective communicators is a huge step forward in student learning.

- There are issues of "ownership" of the IDS project - who owns the ideas and products intellectually? Who makes the decisions on options for product design? Who selects product features? These issues that are related to the ownership of the project and the roles to be played by the students were needed to be clearly defined and explained to the students. This was done up front in Week \#1. It was important to reinforce the concepts of team work and team ownership in this context.

- Engineering students sometimes felt that marketing students went ahead and added product features without discussing with them first to make the product more attractive to the potential customers. So, the students need to learn to "negotiate" with each other to work out what exactly are they going to market and what are they going to actually deliver.

- Lastly, the final choice of the design which the engineering teams would work further to manufacture a prototype was determined by a panel of external marketing professionals to remove any internal team bias and ensure that the decision making process was more objective.

\section{Summary}

An Interdisciplinary Design Studies project was implemented for juniors initially since 2006 and later with modifications made in 2009. Contemporary design criteria of recyclability, sustainability, green engineering and $\mathrm{CO}_{2}$ footprint have been added to the design specifications. Students drawn from Engineering and Marketing worked together as a team to create ideas for consumer products that not only satisfy the given design criteria and constraints, but also have a fair chance of being commercially successful. Pre- and post-course student surveys were conducted to assess the effectiveness of the IDS curriculum. Based on the qualitative analysis of the surveys, it appears that the students seemed to enjoy the learning opportunities that this course offered such as working in interdisciplinary teams, following through a complete design process, interacting with industry professionals, marketing professionals and the hands-on experience. On the other hand, perhaps not surprisingly, the students realized that the main bottlenecks in their way were time and project management, teamwork and communication. Notwithstanding these issues, the student performances in terms of ABET outcomes assessment has improved significantly in the IDS project. The student's satisfaction is also high as indicated by very good data from SIR II surveys as well as post-course satisfaction (feedback) surveys. The IDS project approach has helped identify activities that are working well to enhance student understanding of the subject matter, enrich their learning experience, and to identify areas for further improvement. Many lessons have been learnt over the years via student surveys. The areas for improvements have been many-fold including synchronized scheduling of classes, effectiveness of communication, collaboration amongst team members, scheduling time for joint meetings, inviting panels of industrial experts for assessment and resolving project ownership issues. 


\section{Suggestions for Future Improvements}

Based on the student feedback and the faculty experience, the following suggestions are made to improve the effectiveness of course delivery in future:

- Interdisciplinary interaction could be improved by generating a bunch of ideas already that students may be able to work on to get started with in the course.

- Improvement in time management in the first half of the term, especially more time is needed for manufacturing of the prototype.

- Students feel that interaction between marketing and engineering students needs to be improved. In particular, some engineering students found that the feedback from marketing surveys was sometimes not very useful in generating ideas for redesigning a product due to ineffective communication amongst the team members.

\section{References:}

1. Manufacturing Engineering Plan: Phase I, (1997). Manufacturing Engineers Education Foundation, Dearborn, MI.

2. Manufacturing Engineering Plan: Phase III, (2003). Manufacturing Engineers Education Foundation, Dearborn, MI.

3. V. Jovanovic and M. Tomovic: A Competency Gap in the Comprehensive Design Education, Proceedings of the ASEE Annual Conference, 2008.

4. S. Lai Yuen \& M. Herrera: Integrating Real-World Medical-Device Projects into Manufacturing Education, Proceedings of the Annual ASEE Conference, 2009.

5. I. Heng, A. S. Zhang, F. Zia: New Approach to Teach Product Design That Breaks the Discipline Boundaries, Proceedings of the Annual ASEE Conference, 2011.

6. M. Grimheden: Education for Product Innovation: A "Good Practices" Report, Proceedings of the Annual ASEE Conference, 2009.

7. D. Wells: A Model for Integrating Entrepreneurial Innovation into an Engineering Capstone, Proceedings of the Annual ASEE Conference, 2010.

8. R. Scozzari, and J. Astwood: Interdisciplinary Sustainability Design and Development Education: Research, Development and Discovery, Proceedings of the Annual ASEE Conference, 2011.

9. E. Pappas and R. Kander: Sustainable Societies: The Sustainable Engineering Design Curriculum at James Madison University, Proceedings of the Annual ASEE Conference, 2008.

10. K. Lewis, D. A., Moore-Russo, O. M. Ashour, T. W. Simpson, G. E. Okudan Kremer, X. Neumeyer, A. F. McKenna and W. Ches: Teaching the Global, Economic, Environmental and Societal Foundations of Engineering Design Through Product Archeology, Proceedings of the Annual ASEE Conference, 2011.

11. D. Shetty and S. Choi: Globalization and Product Design Curriculum in Engineering Programs, Proceedings of the Annual ASEE Conference, 2003.

12. D. Nieusma: Integrating Technical, Social and Aesthetic Analysis in Product Design Studio: A case Study and Model for a New Liberal Education for Engineers, Proceedings of the Annual ASEE Conference, 2008.

13. W. Loendorf, D. Richter, and D. Teachman: Results from an Interdisciplinary Service Learning Pilot Project Incorporating Universal Design Concepts for ADA Compliance, Proceedings of the Annual ASEE Conference, 2010.

14. P. A. Manohar, C. Jones and J. Radermacher: Development and Implementation of a Junior-Year Design Course in an Interdisciplinary Environment Along with Media Art and Marketing, Proceedings of the Annual ASEE Conference, 2007. 